\title{
The exposition of John 17:6-8: An exegetical exercise
}

\author{
D G van der Merwe \\ Department of Religious Studies \\ Vista University
}

\begin{abstract}
This essay is an exegesis of Jn 17:6-8 aimed at gaining an understanding of what the Fourth Evangelist tries to emphasize and to communicate concerning the character and success of Jesus This essay is an exegesis of Jn 17:6-8 aimed at gaining an understanding of what the Fourth Evangelist tries to emphasize and to communicate concerning the character and success of Jesus' earthly ministry. Firstly, a discourse analysis is conducted to point out the linguistic symmetric parallelism through which the Evangelist (1) emphasizes the success of Jesus' ministry, (2) structures the principal components of Jesus' ministry and the response of his disciples and (3) tries to explain the meaning of these components. Secondly, a theological exposition of these principal components is conducted, in respect of

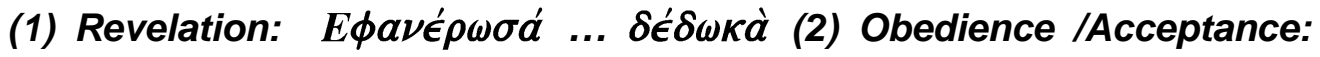

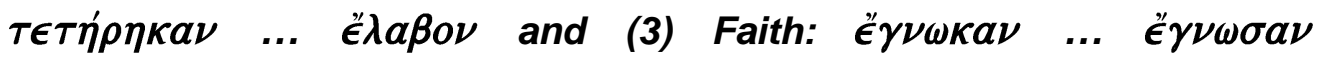

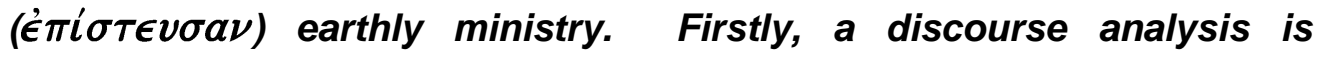
conducted to point out the linguistic symmetric parallelism through which the Evangelist (1) emphasizes the success of Jesus' ministry, (2) structures the principal components of Jesus' ministry and the response of his disciples and (3) tries to explain the meaning of these components. Secondly, a theological exposition of these principal

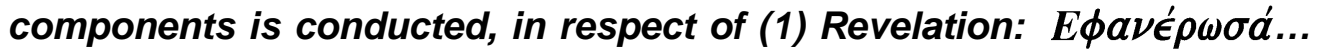

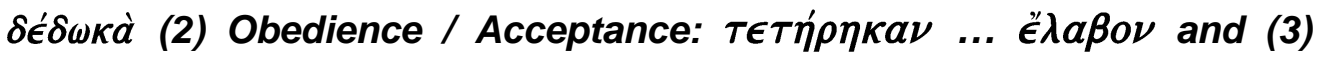

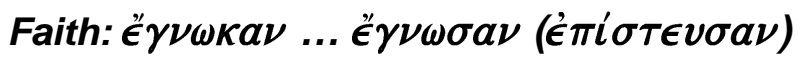

\section{INTRODUCTION}

Jesus, in reviewing his earthly mission, declares that he has accomplished the task the Father had assigned to him (17:4), and through this has glorified the Father. This report of Jesus to the Father can be found in John 17:1-8. The 
work to which Jesus refers as being completed, is the divine revelatory-salvific task he came to perform. In vv 2, 3 he refers to his salvific work, and in vv 6-8 he reports on the revelatory work that he has accomplished successfully ( $v 4) .{ }^{1}$ This part of Jesus' report can also be seen as the attestation of his disciples. This is important information regarding the lives of the disciples which makes them legitimate candidates to be appointed by Jesus to continue his divine mission (17:17-19).

Verse 2 mentions the men that God had given to Jesus, and states that

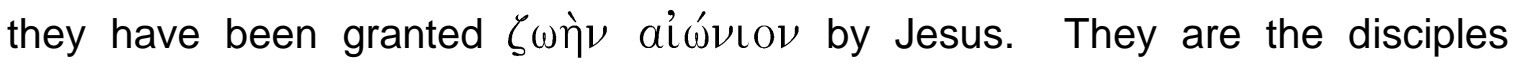
present, who have accepted his words and believe in him as the one who came from God and was sent by God ( $v 8)$. He characterizes them as belonging to God and contrasts them with the "world". In vv 6-8 Jesus elaborates on the event of their salvation by describing how it was mediated through revelation. This then completes the reference to the successful revelatory-salvific work of Jesus referred to in $v 4$.

The aim of this exegesis of $\mathrm{Jn} 17: 6-8$ is to gain an understanding of what the Fourth Evangelist tries to emphasize and to communicate concerning the character and success of Jesus' earthly ministry. Firstly, a discourse analysis will be conducted in order to point out the linguistic symmetric parallelism through which the Evangelist (1) emphasizes the success of Jesus' ministry, (2) structures the principal components of Jesus' ministry and the response of his disciples, and (3) tries to explain the meaning of these components. Secondly, a theological exposition of these principal components will be conducted.

\section{A DISCOURSE ANALYSIS ${ }^{2}$ OF JOHN 17:6-8}

This cluster contains the entire Johannine theology of revelation and the community of salvation in condensed form (Schnackenburg 1975:198f).

\footnotetext{
1 Verses $2 f$ refer explicitly to the salvific work of Jesus but imply revelation as the result of salvation, while in vv 6-8 the revelatory work of Jesus is emphasized and salvation is seen as the result of the revelation. Salvation and revelation cannot be interpreted separately for they are

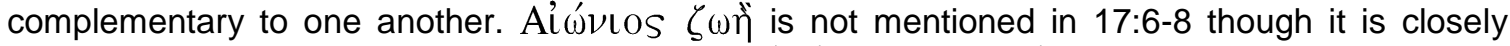

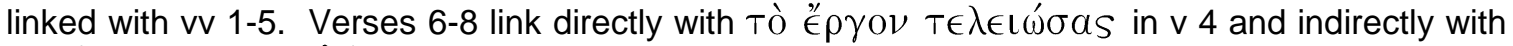

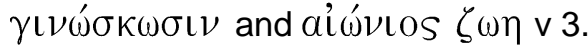

2 The discourse analysis used in this article was developed by members of the New Testament Society of South Africa, based on the pioneering work of $J$ P Louw since the late sixties. See Louw, J P 1982. Semantics of New Testament Greek. Philadelphia: Fortress Press Chico.
} 
Newman and Nida (1980:523f) agree that the theme of this cluster is revelation.

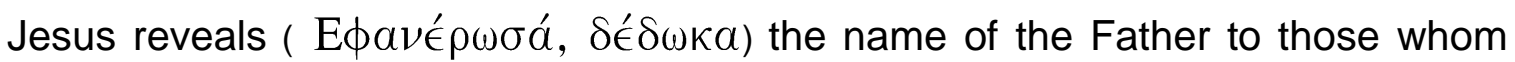
the Father has given to him. They respond by accepting ( $\left.{ }^{\prime} \lambda \alpha \beta \beta \nu\right)$ the revelation, coming to faith ('́ $\gamma \nu \omega \sigma \alpha \nu)$ in Jesus and obediently directing ( $\tau \epsilon \tau \eta ́ \rho \eta \kappa \alpha \nu)$ their lives according to Jesus' teaching.

The following is a discourse analysis of Jn 17:6-8:

Linguistic structure

Semantic relations

\section{Subdivision A}

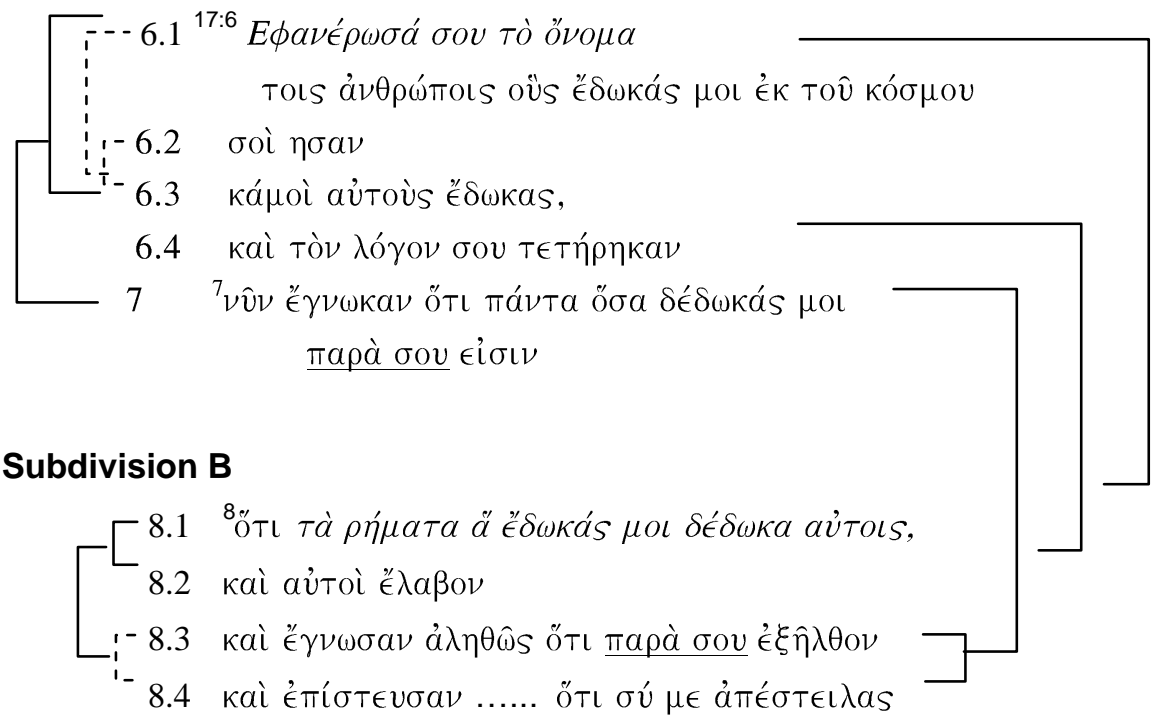

\subsection{Discussion of the linguistic structures}

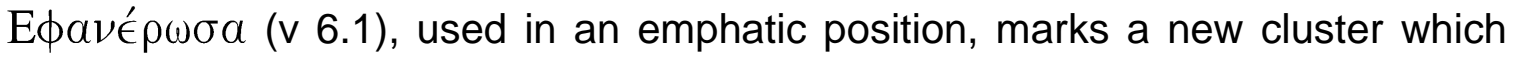
closely relates to vv 1-5. The content of verses 6-8 is an elaboration of $v 4$ (also reflected in vv 2, 3; see footnote 1 for motivation). Even in the Greek-English New Testament (Nestle-Aland 1979:305) these verses are combined into a paragraph. Furthermore the linguistic structure of the discourse analysis and specific vocabulary construct it as a unit.

- $\quad$ Subdivision A: Verse 6.2 links with 6.3 through the copulative particle kai, and because the verb $\in i \mu i$ ( $3^{\text {rd }}$ person plural) refers to the personal 
pronoun aưTós ( $3^{\text {rd }}$ person plural). In both the content indicates possession. Verses 6.2 and 6.3 are linked with verse 6.1 through the verb, É $\delta \omega \kappa a s$ which occurs in both verse 6.1 and 6.3. The relative pronoun oús (accusative in $\vee 6.1$ ) also refers to the personal pronoun aưToùs (accusative in $\vee 6.3$ ). Verse 6.4 is consecutively linked with $\vee 6.1-3$ through the copulative particle kaì, indicating the consequence ( $\leftarrow \in T \eta ́ \rho \eta \kappa \alpha \nu)$ of the revelation. Verse 7 is linked with $\vee 6.1-4$ by the adverb $\nu \hat{v} \nu$. The $\nu \hat{v} \nu$ in $v 7$ is not used in a temporal sense in terms of consequence, but rather in a causal sense to indicate that the event in $\mathrm{v}$ 6.4 is temporally the result of that which takes place in $v 7$, owing the fact that the standpoint of the prayer is that of the post-resurrection Church (Sanders 1975:370).

- $\quad$ Subdivision B: Verse 8.1 is linked with 8.2 by the copulative particle кai;; Here kaì has the same causal function as the adverb $v \hat{v} \nu$ in $v 7$. The

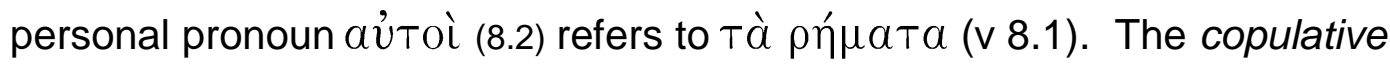
particle kai also links $\vee$ 8.1-2 with 8.3. Verses 8.3 and 8.4 form a parallelism.

Although verse 8 is linguistically causal (ÖTl-clause) to verse 7 , it starts a new cycle of explanation which ends on the same note as verse 7. Even the linguistic structures of the two subdivisions correspond. We can say that these two subdivisions form a linguistically symmetric parallelism and are mutually elucidating, as will become clear. Also, on a theological level, this section (vv 6-8) contains two equal subdivisions ( $\mathrm{vv} 6,7$ and 8 ) which are molded into a theological parallelism. Both structures in these two subdivisions express progression in the disciples' knowledge of Jesus through the use of the copulative particle kal (vv 6:4, 8:2 \& 8:3).

\subsection{Discussion of the semantic relations}

The following verses relate to one another: $v$ 6.1-8.1, 6.4-8.2; and 7-8.3 and 8.4. This method of developing and amplifying a theme also reflects the Johannine 
spiral movement of thought ${ }^{3}$. In both subdivisions there is a theological development from the point of revelation $(v 6.1,8.1)$ to the point of response by obedience ( $v 6.4,8.2)$, introduced by a copulative particle kai. This was constituted by the acceptance (' $\left.\epsilon^{\prime} \lambda \alpha \beta O \nu\right)$ of this revelation which led to the disciples' faith in Jesus $(7 ; 8.3 ; 8.4)$, introduced by an ÖTı particle. Jesus' disciples came to know that Jesus was of divine origin, that he had come from God. They came to believe that the Father had sent Jesus to execute a divine task (cf Morris 1975:724f).

The following is a presentation and a summary of the soteriological development indicated in these subdivisions.

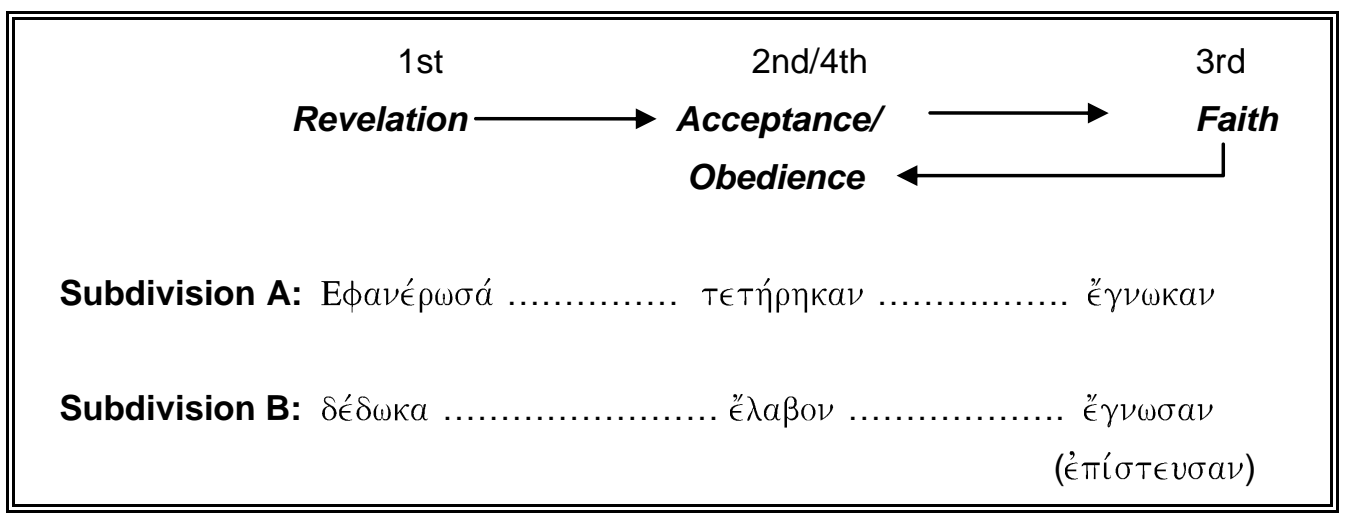

These soteriological components will now be discussed.

\section{A THEOLOGICAL DISCUSSION OF THE MAIN IDENTIFIED SOTERIOLOGICAL COMPONENTS}

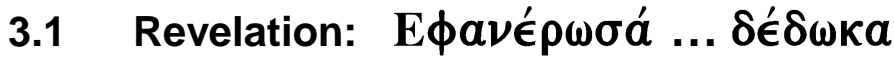

According to the Fourth Evangelist no one really knows God. In 1:18 it is said

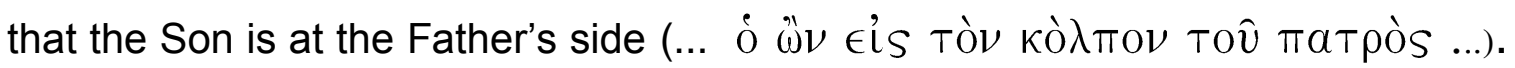

\footnotetext{
3 The Fourth Evangelist's movement of thought "circles" around certain concepts; but still moves forward while remaining within a circle. This movement of thought is best compared to a spiral: although the thoughts circle and return, they still move onward. The forward movement it is explanatory and usually goes to a higher level (cf Schnackenburg 1965:115; Van der Merwe 1995:4).
} 
If we want to know God, it can only be through the Son, because he is the only

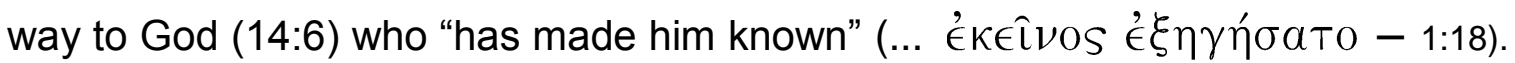
Therefore the Son of Man incarnated into this world to reveal God $(1: 14,18)$. In vv

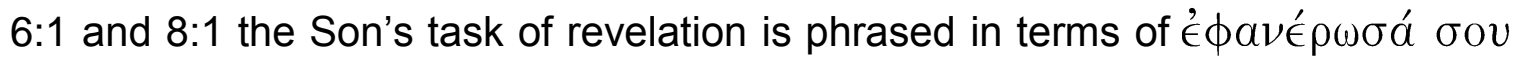

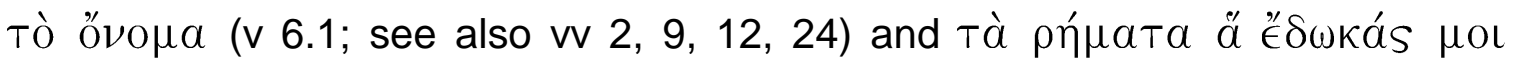

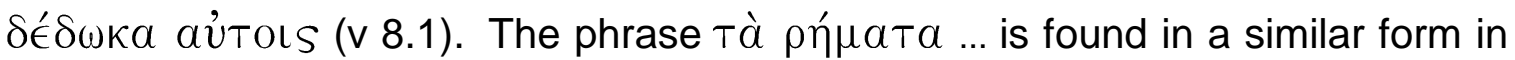

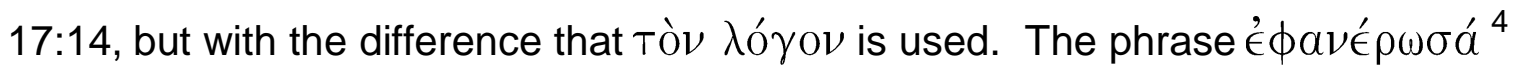

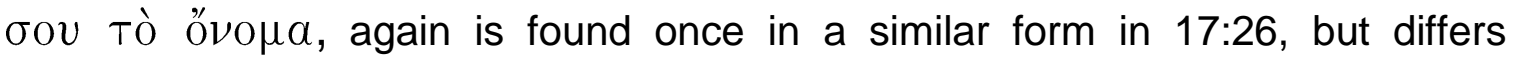
somewhat in that the verb $\gamma \nu \omega \rho i \zeta \in \mathrm{L} \nu$ is used ${ }^{5}$ to bring out the full meaning of revelation. The revelation of the Father becomes clearer when these four references are compared:

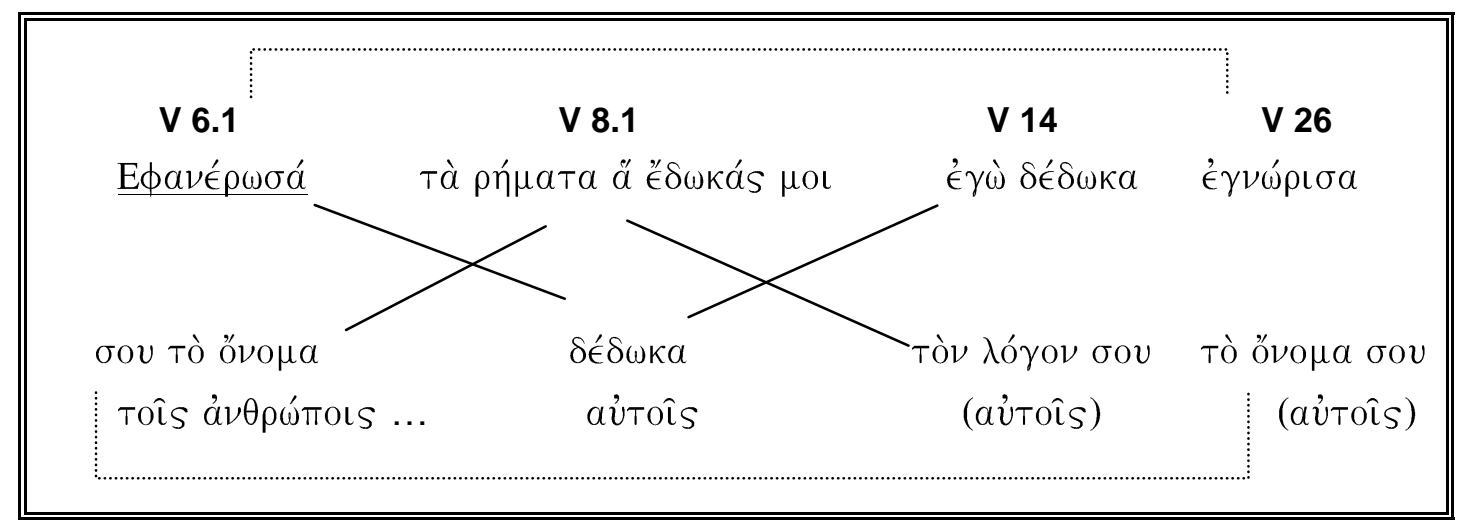

The chiasms and parallelisms in the above comparison emphasize the close

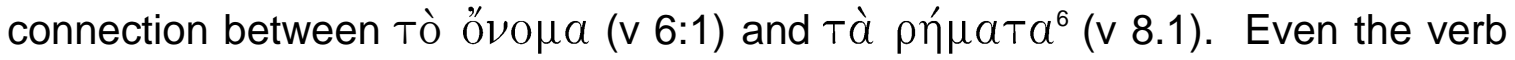

4 The verb é $\phi a \nu \epsilon^{\prime} \omega \sigma \sigma a ́$ occurs elsewhere as a term of revelation in terms of the manifestation of Jesus (1:31; 7:4), his glory (2:11) and the works of God (9.3). According to Lenski (1961:1128f), "The aorist records the accomplished fact while the verb фavè pov̂v is comprehensive, to 'make visible and clear,' ... somewhat like 'to reveal' by all that Jesus is, says, and does." Barrett (1978:505) and Carson (1991:558) agree with Lenski; the aorist, '́́ $\phi a \nu e ́ p \omega \sigma a ́$ sums up the work of the ministry of Jesus. According to Carson it also includes the cross. Danker (2000:1048) agrees that it refers to the "make known" through Jesus' teaching, accompanied by a revelation that comes through a deed.

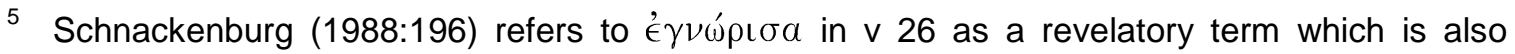

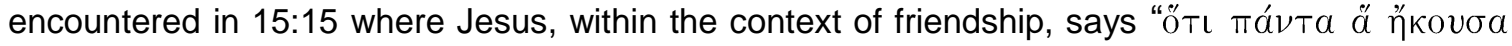

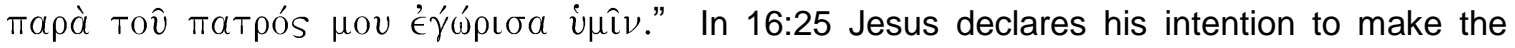
Father's name known.

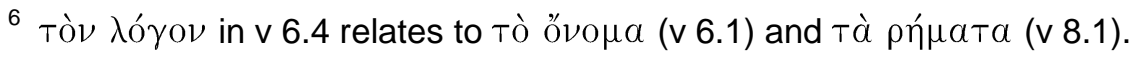




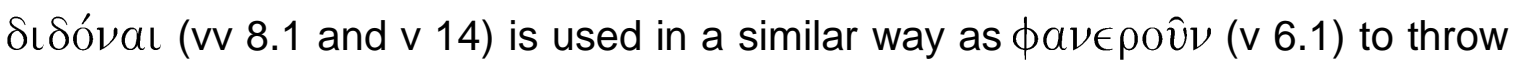
light on the fact that Jesus has given his disciples $\tau \grave{\alpha} \rho \eta \dot{\mu} \mu \alpha \tau a$, given to him by

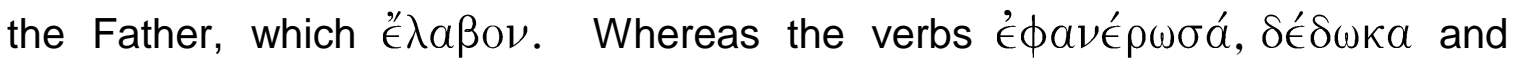
É $\gamma \nu \omega \rho \iota \sigma \alpha$ indicate the act of revelation (by Jesus) the phrases $\sigma o v$ Tò

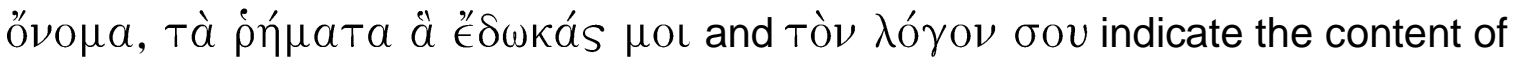
the revelation (by Jesus).

Through these events of revelation Jesus brought the "above" into the "below". He did this without becoming part of the "below". Van der Watt (1991:108) very aptly points out the fact that because the Johannine dualism concerns a person-dualism, which resides in the qualities of the person, it becomes possible for Jesus to act on earth without becoming qualitatively part of the mundane. Therefore, it can be stated that Jesus' words are always God's words (5:19-30), he bears the name of God (e g 17:6, 11, 12, 26) (Thompson $2001: 123)$, Jesus himself is the self-expression of God. Jesus keeps the word of God (8:55), his commands (15:10), and encourages his followers to observe his word $(8: 51,52 ; 14: 23)$ or words $(14: 24)$ and his commands $(14: 15,21 ; 15: 10)$. The fact that '́ $\phi a \nu \hat{\epsilon}^{\prime} \rho \omega \sigma a ́$ is in the aorist, sums up the total revelation of God in the ministry of Jesus (Newman \& Nida 1980:530). His incarnation, his teaching, his miracle-working, his encounters with people, and indeed his entire life, are placed within the all-embracing context of revelation. "As the narrative of the Gospel proceeds, the revelatory path of the Logos among human beings is developed and the saving significance of Jesus Christ is reflected upon" (Schnelle 1998b:510). Through all this he brings to mankind the distant and totally other God. He is the visible manifestation of the invisible God, the only way to the Father. As Medium he is simultaneously both the Bringer and Content of the revelation (Schwankl 1995:372). Thus, in Jesus' work, his ministry, God himself is at work, in him God himself is encountered (Bultmann 1941:381).

But what does the Fourth Evangelist mean with the expression $\sigma o v$ tò óvo $\mu a$ According to the expressions in $17: 11,12,26$ the interpretation of the phrase in $\vee 6.1$ goes beyond the literal. For the Fourth Evangelist ovo $\mu \alpha$ is

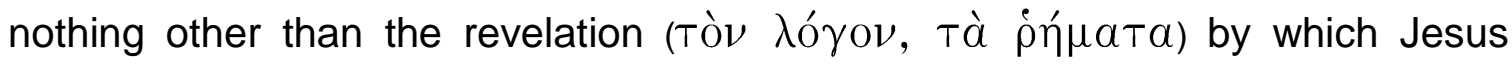
makes God knowable. Newman and Nida (1980:530) maintain that the reference 
to Tò oै $\nu \rho \mu a$ of God is another way of referring to God directly. According to Schnackenburg (1975:199, Bernard 1963:564 and Morris 1975:723) бov Tò ó $\nu$ o $\alpha$ a refers to God's being and nature (also see 12:28, and especially 17:11), his holiness, righteousness and love (the disclosure of God himself, which is the disclosure of the $\alpha \lambda \eta \dot{\theta} \theta \iota \alpha$ - Bultmann 1941:381; cf Lenski 1961:1129), ${ }^{7}$ which are certainly expressed in the address to the Father and the attributes connected with the name. Sanders (1975:369), Carson (1991:558) and Lindars (1981:521) are of the opinion that the aforementioned refers to the character and person of God, which were proclaimed throughout the ministry of Jesus and included even the cross. This description of God's character and person was given to Jesus by God himself ( $v$ 8.1; also 12:50). Schenke (1998:324) epitomizes the above statements about the meaning of $\sigma \circ v$ Tò ô $\nu \rho \mu a$ beautifully in "Mit seinem Namen tritt der unbekannte Gott (vgl. 1, 18; 4, 22; 5, 37; 8, 19) aus der Verborgenheit (Ex 3, 13ff; Jes 52, 6; Ez 39, 7) hervor; er erschließt sich und wird zugänglich. ... In Jesus hat sich Gott irdisch gezeigt (1, 14; 8, 19; 10, 30:38; 14, 7-10) und als der 'einzige, wahre Gott erkennen' lassen (17, 3)." In accepting the words of God the disciples acknowledge the content as the revelation of God in Jesus (Schnelle 1998a:256).

According to the abovementioned chiasms and parallelisms, $\sigma 0 v$ Tò

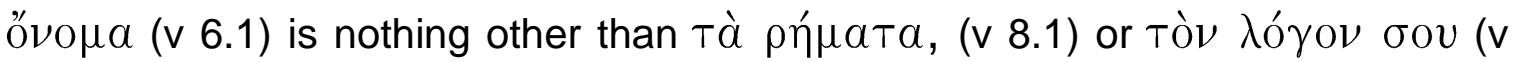
$14)$, which God had given to Jesus. All three references refer to the revelation of God that comes through Jesus (Newman \& Nida 1980:531; also Wilckens 1998:263).

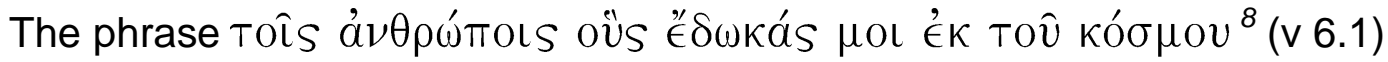
refers to the disciples of Jesus. This gift was not rooted in anything intrinsically good in these people themselves. They were part of the wicked world, but God

7 For the Semites a name was the expression of a person's character and power. Hence, making known God's name to the disciples would mean to reveal the character and power of God to them. This revelation took place through the person, words and works of Jesus. Bultmann (1941:381) rightly observes that in Jesus' work, God himself is at work, in him God himself is encountered.

8 The second part of the Fourth Gospel indicates a change from a teacher-disciple relationship between Jesus and his disciples to a more intimate relationship, as is indicated by the following

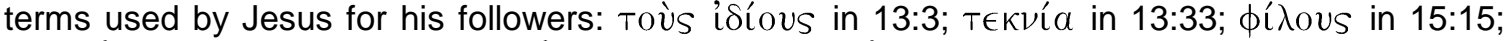

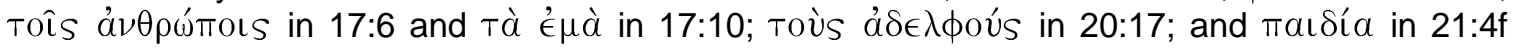
(Köstenberger 1998:153). 
took them out of the world and gave them to Jesus - which is functionally equivalent to being chosen by Jesus from out of the world (15:19) (Carson 1991:558). They are the people who have responded to Jesus during the time of his ministry. This thought in v 6.1 recurs throughout Chapter 17 (vv 2, 9, 12, 24). From now on ( $v 18$ ) the disciples will be the agents of Jesus for the expansion of his work (Lindars 1981:521). This implies that through these disciples the world will meet God as they experience God in Jesus. Thus the character and work of God must be revealed through them. The world must see and encounter God and Jesus in the lives of the disciples.

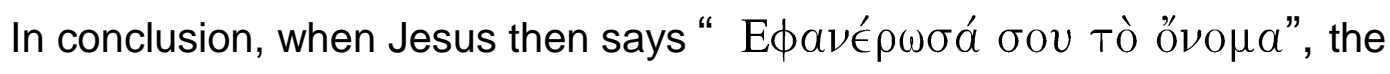
intention is to convey that he gave to his disciples "all the information that they needed to know God" (cf $3: 16,17 ; 4: 34 ; 6: 38 f ; 12: 49 f$ and 5:36f for other examples of Jesus' acts of revelation). This is shown by the parallel between

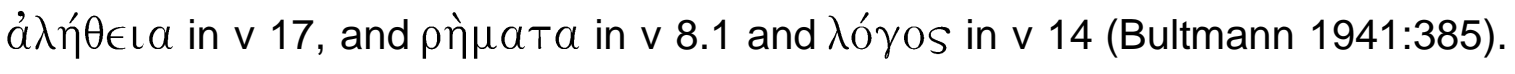

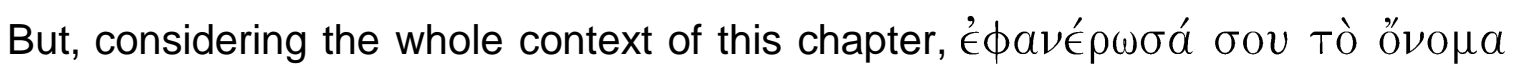
not only refers to the character and person of God, but also defines implicitly the way of life that characterizes the life of the disciple who perceives the revelation of God by the Son of God. Knowing God, implies that God lives in the disciples, and that their way of life corresponds with the character of God. It also relates to the mission to which they will later be appointed by Jesus. This is the content of the revelation which Jesus himself received from God and communicated to his disciples through his life, words and deeds ( $\mathrm{v} 8.1$ ).

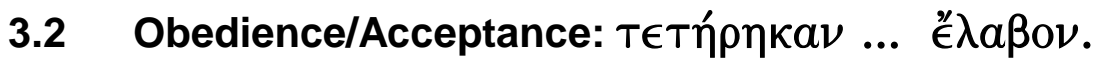

These two phrases, which occur in vv 6.4 and 8.2, form a parallelism and can be structured as follows: 


\begin{tabular}{|c|c|}
\hline V 6.4 & V 8.2 \\
\hline каı & кaì \\
\hline 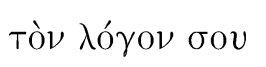 & 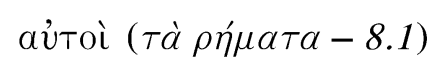 \\
\hline 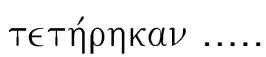 & $\stackrel{\epsilon}{\epsilon} \lambda \alpha \beta o \nu$ \\
\hline
\end{tabular}

This parallelism is constituted in the sense that their linguistic construction is the same, and that they both concern the word(s) (revelation) of God, except that v 8.2 refers to the cause (" $\mathrm{k} \lambda \alpha \beta \mathrm{O} \nu$ ) of the relationship between Jesus and his disciples while $\vee 6.2$ refers to the effect ( $\tau \epsilon T \eta ́ \rho \eta \kappa \alpha \nu)$ of this relationship. These two aspects will now be discussed.

\subsection{Kaì aủToì é $\lambda a \beta o \nu$}

The disciples know the truth, the revelation about God, because Jesus has given it to them and they have received $\left(\epsilon^{\prime} \lambda \alpha \beta O \nu\right)$ it. But what does the Fourth Evangelist try to communicate by using the verb $\lambda \alpha \mu \beta a ́ v \in \iota \nu$ ? In 12:49 (also

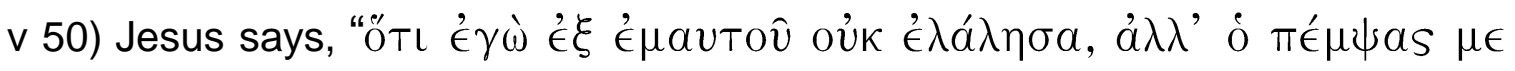

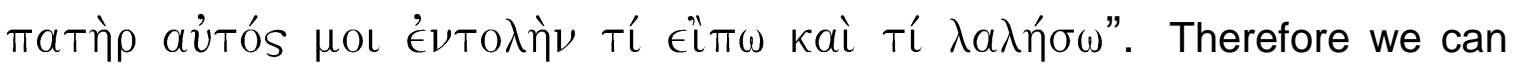
state that Jesus' words are the Father's words, and the words of the Father are

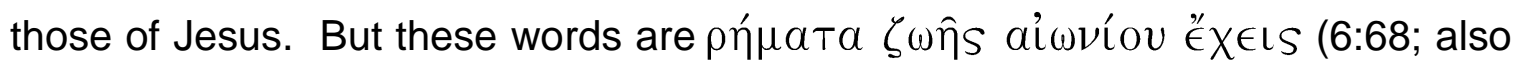
6:63). When the disciples accept/receive ( $(€ \lambda \alpha \beta O \nu)$ these words they receive

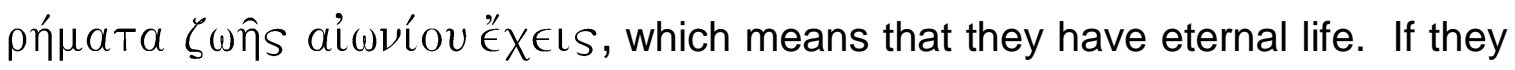
have eternal life, the implication is that Jesus lives in them (cf 1:12f; 3:16; etc). Through his words (and the Paraclete) Jesus lives in his disciples. This statement makes sense in the comparison between 15:4 and 15:7. These two verses clearly form a parallelism from which we can make the following deduction: 


\begin{tabular}{|c|c|}
\hline 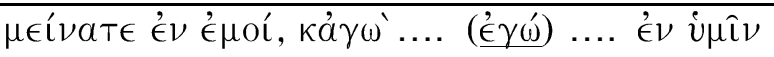 & v 4 \\
\hline 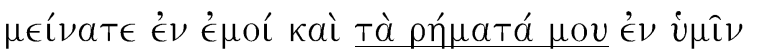 & $\vee 7$ \\
\hline
\end{tabular}

Because these phrases form a parallelism Jesus $(\underline{\epsilon} \gamma(\hat{\omega})$ can be substituted by

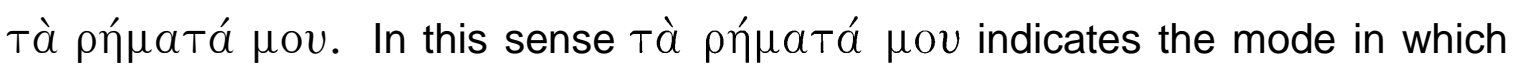
Jesus remains in his disciples to edify and transform their lives (Van der Watt

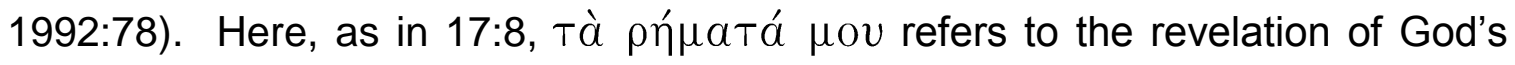
character, all the information the disciples needed in order to know God. According to Barrett (1978:475), these are the things that must remain in the mind of the believer. The reason why Jesus does this is because his revelation

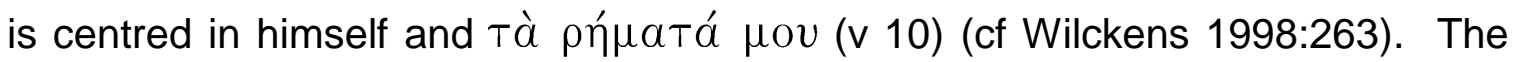
person of Jesus and his revelation are often interwoven in the Fourth Gospel. Thus, when a person believes in Jesus his entire life-orientation, his life and world contemplation and his conduct are changed and directed by the revelatory words of Jesus. This concerns in particular, the performing power of these words. These words influence the believer concretely and dynamically because they are linked to the person of Jesus: they do what Jesus would have done to

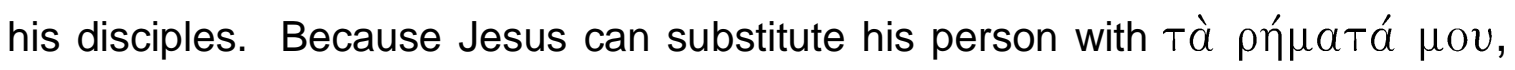

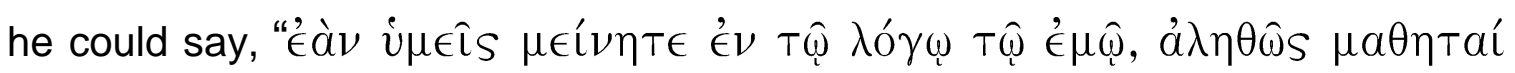

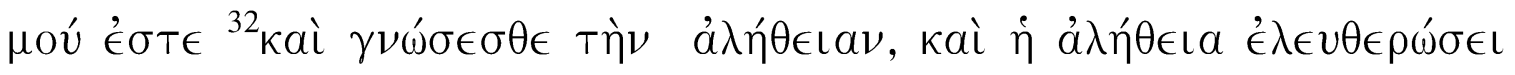
vंuas" (8:31f).

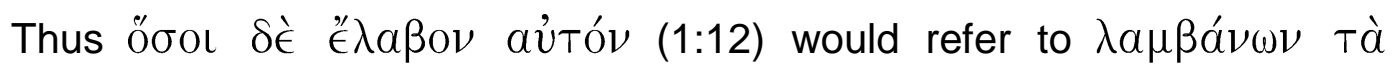
$\rho \eta ́ f a \tau a ~ \mu o v ~(12: 48$ and 17:8) and is actually a pregnant expression of the

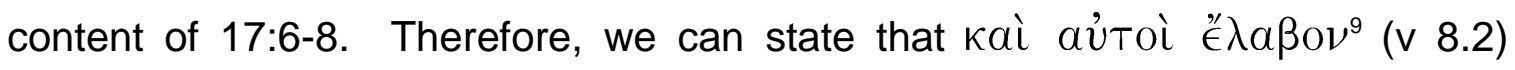
refers to the moment of a believer's repentance when he has accepted the words

9 The verb $\lambda \alpha \mu \beta a ́ v \omega$ occurs 46-times in the Fourth Gospel and has a broad range of meanings. Relevant to our discussion and from the immediate context $\epsilon^{\prime} \lambda \alpha \beta o v(v$ 8.2) would mean: when a person accepts the "word" which Jesus brought ( $v$ 8.1), he attests the truth of God (3:32f) and lives by it. Thus it can be concluded that the person who '̈ $\lambda \alpha \beta \rho \nu$ God's word of revelation in Jesus also has accepted its full practical implications. In this sense '̈ $\lambda \alpha \beta o \nu$ relates not explicitly, but by implication, to $\tau \epsilon T \eta ́ \rho \eta \kappa \alpha \nu$ in $\vee$ 6.4. Barrett (1978:506) explains that by receiving the words of Jesus the disciples received life ( $\vee 2)$. 
of Jesus - that is Jesus himself. The aorist ( $\left.\epsilon^{\prime \prime} \lambda \alpha \beta o \nu\right)$ refers to a definite act completed in the past. This refers to the beginning of the new relationship between Jesus and his disciples.

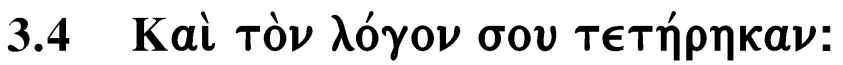

If ' ${ }^{\prime} \lambda \alpha \beta o \nu(v 8.2)$ refers to the cause of the relationship between Jesus and his

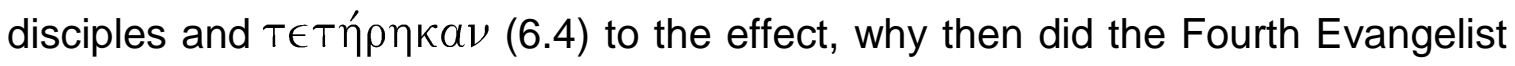

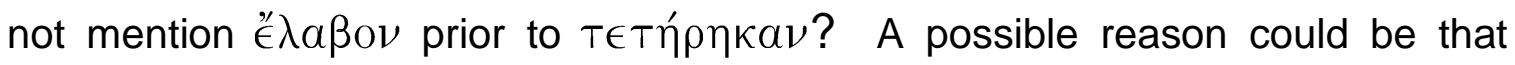

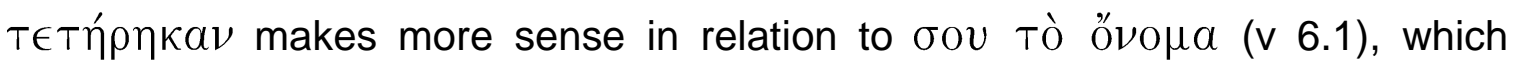
explains why the perfect tense is chosen to refer to the living of a life according to

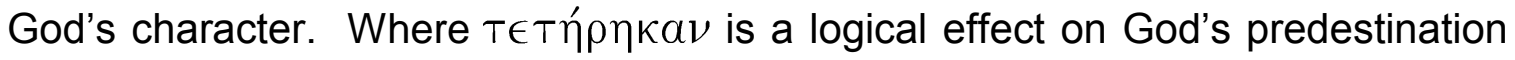

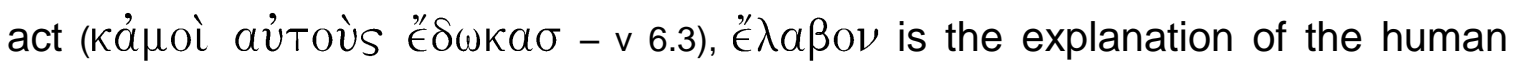
response on hearing God's Word in the salvation process (cf 1:12) and is closely

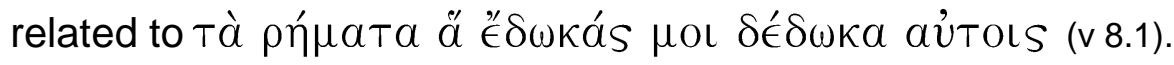

It is necessary at this point also to elucidate briefly on the sequence of and relationship between $\tau \epsilon T \eta ́ \rho \eta \kappa \alpha \nu(\vee 6.4)$ and $\epsilon^{\prime} \gamma \nu \omega \kappa \alpha \nu(v 7)$. It has already been indicated that the particle $\nu \hat{v} \nu(\vee 7)$ is used to explain why the event in $\vee 6.4$ took

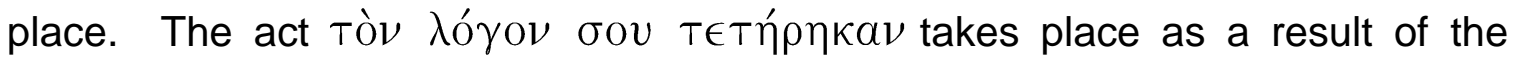

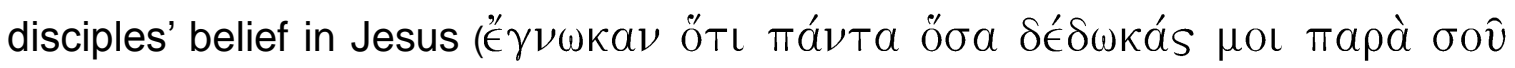
$\epsilon i \sigma(\nu)$. The act in $\vee 7$ thus took place prior to that indicated in $\vee 6.4$.

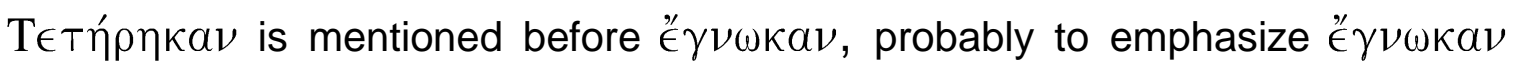
and the content of the faith of the disciples. The situation of the Fourth Evangelist at this particular time also has to be considered here. That the

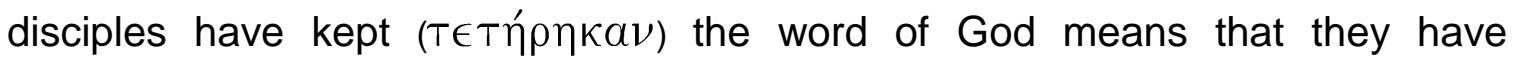
accepted ( $(€ \lambda \alpha \beta O \nu)$ and faithfully proclaimed the truth of God in Jesus. This, according to Barrett (1978:505), can hardly refer to the period of the ministry of Jesus (especially the view of $16: 31 \mathrm{f}$ and similar passages). Viewed from the post-resurrection perspective by the Fourth Evangelist (Lindars 1981:522, cf Barrett 1978:505), the Fourth Evangelist is looking back (perhaps from the end of the first century) upon the work of the apostles. Brown (1972:743) and Lindars (1981:522) agree that this statement ( $v 6.4)$ is an anachronism. According to him 
the idea that the disciples had kept God's word in the past and were still keeping it (perfect tense) is out of place at the Last Supper. In 8:51 and 14:23 men are asked to obey Jesus' teaching. At the Last Supper it is clear that the disciples do not yet fully understand $(14: 7,9 ; 16: 5,18)$. Jesus even casts doubt on their claim that they believe (16:31).

In the rest of this prayer Jesus prays for the particular needs (vv 9-16) and prescripts ( $v v 17,18,20-23$ ) of the disciples to equip them to continue his mission through a new way of life - discipleship (cf Lindars 1981:522). God's provision in these needs and the obeying of the prescripts by the disciples are

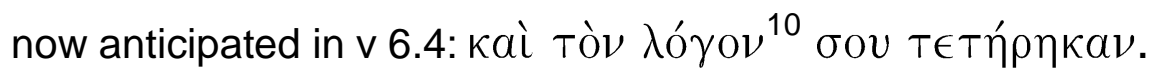

But it is especially 14:23 that is of great value to determine the meaning of

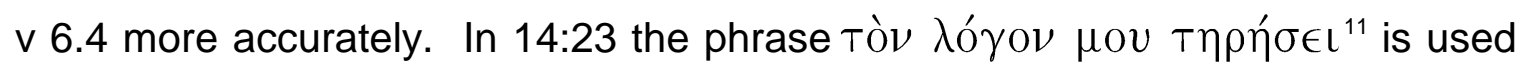

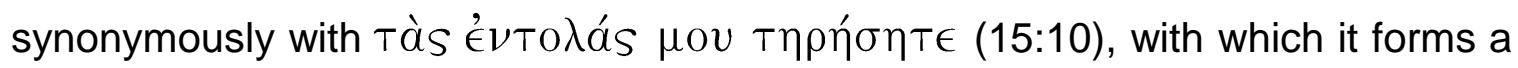
chiasm.

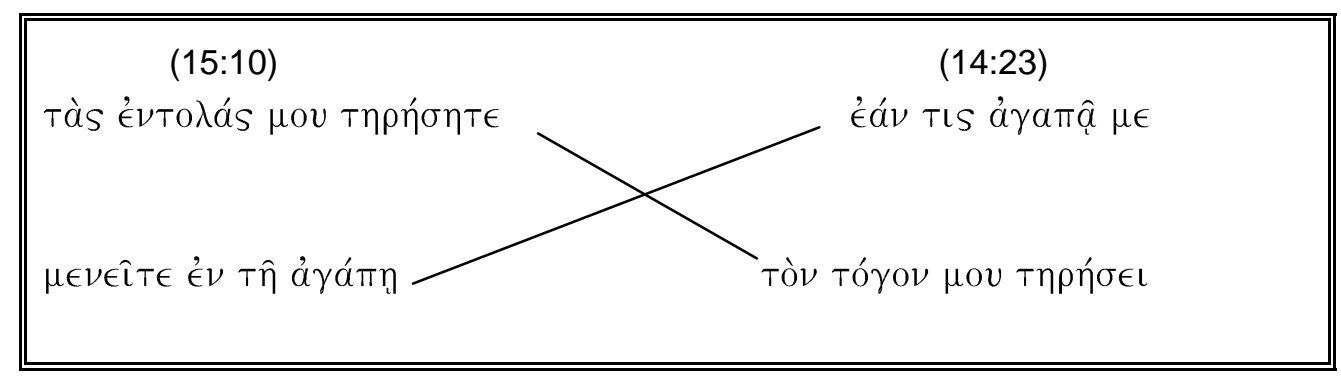

In the Fourth Gospel Christian action is based on divine love. It finds expression

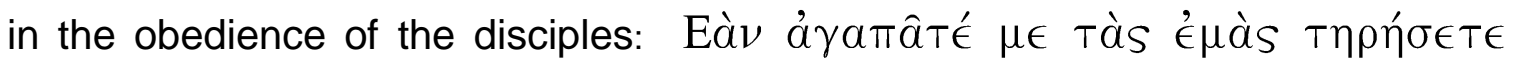
(14:15; cf 14:21). The '́vToגaí are thus to be related to the "new

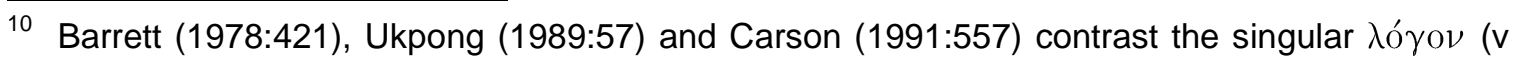
6.4) with the plural $\rho \eta \mu \alpha \tau \alpha$ ( $v 8.1$ ). According to them the singular refers to the divine message as a whole, while the plural refers more specifically to "precepts". Such a distinction is not convincing since the text contains no such indications (cf also Brown 1972:743). From the

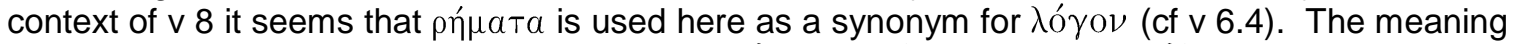

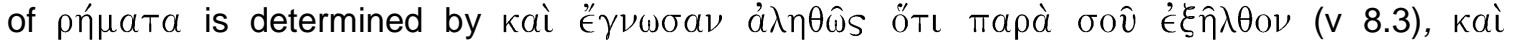

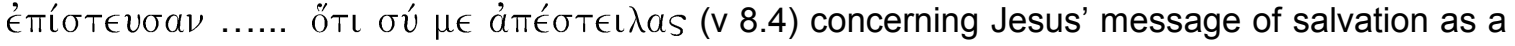
whole.

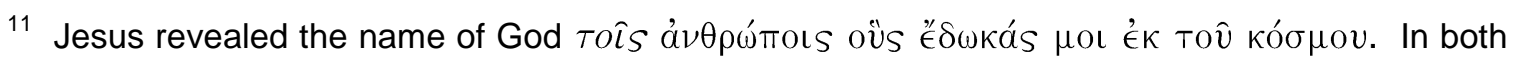
8:51 (cf 8:31) and 14:23 the exhortation to keep Jesus' word is heard. In 6:60 Jesus' disciples (except the "Twelve") could not accept his teaching and left his company. 


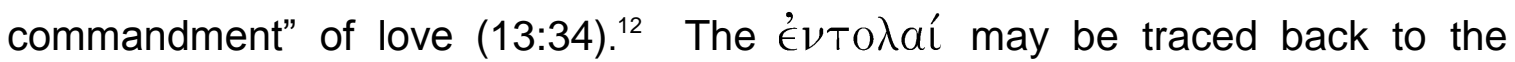
revelation which Jesus brought. His love and obedience to the Father provide the starting point and model (8:55; 15:10) (Riesenfeld 1969:144).

Believers in Christ should not allow themselves to be prevented from holding on to Jesus' word and observing it. Both these ideas are probably

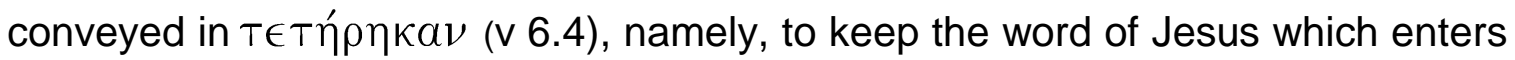
into the person as the word of God and becomes powerful in him (cf 15:3; 17:6, $14,17)$, and to meet the demands contained in this word $(14: 21,23)$. These two

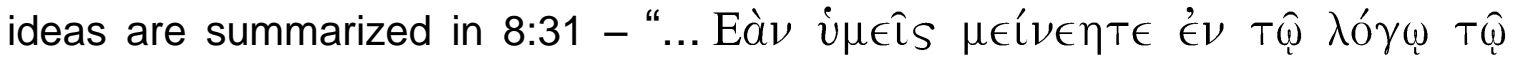

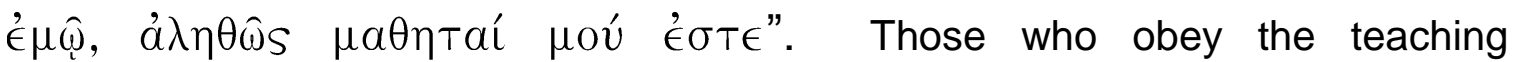
( $\tau \epsilon T \eta ́ \rho \eta \kappa \alpha \nu)$ of Jesus characterize themselves as becoming true disciples of Jesus (8:31).

The following texts are some of the aphorisms in the Fourth Gospel which explicitly refer to the fact that the fulfilment of particular acts characterizes people as disciples of Jesus. This is definitely a reflection on discipleship. Some of these texts are:

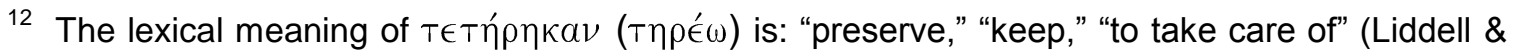
Scott 1974:704; Schütz 1976:132). Schütz (1976:133) correctly, states that all the Johannine passages, whether they are concerned with the keeping of the word or commandments by the disciples $(8: 51 ; 15: 10 ; 17: 11,15)$ are concerned with remaining in Christ. In the Last Discourses $(14: 15,21,23 f)$ there is a special shade of meaning; love for Christ is described as a personal and immediate relationship with him. 


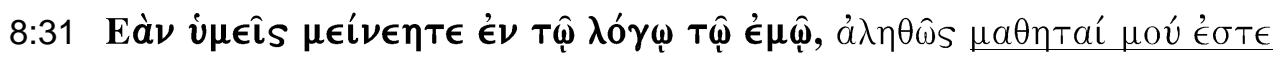

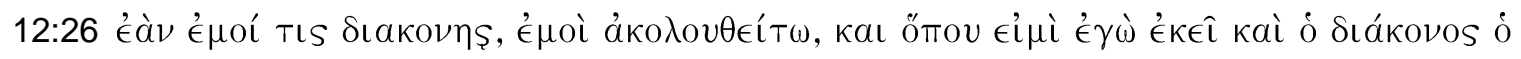

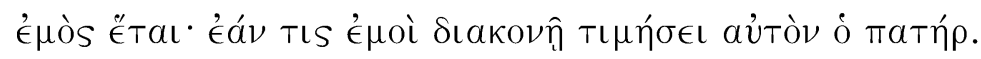

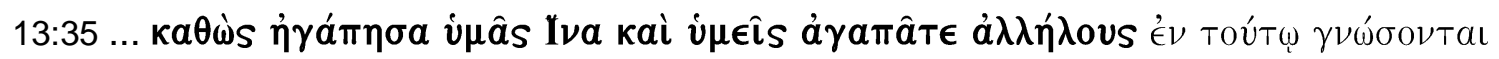

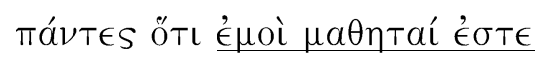

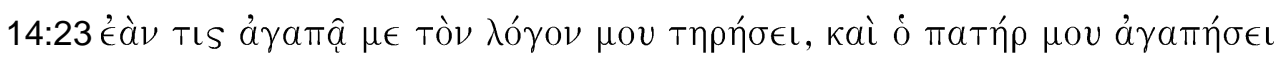

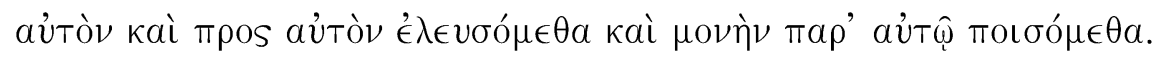

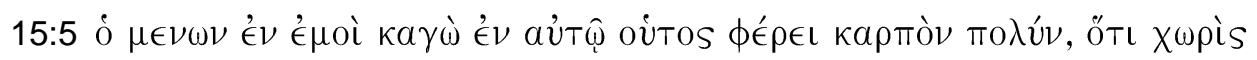

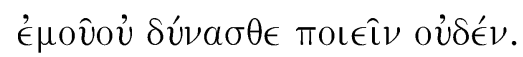

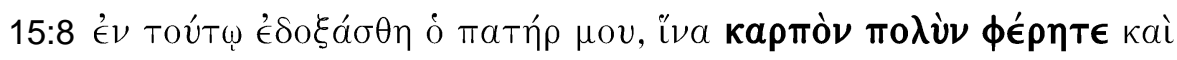

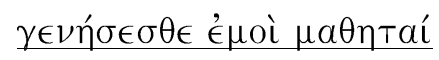

Those who do these things are those who kaì aùTor (

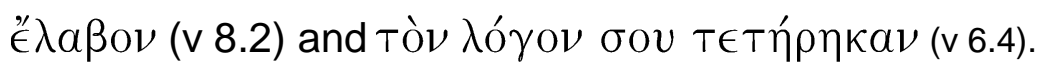

In conclusion it became clear that the Fourth Evangelist in his references

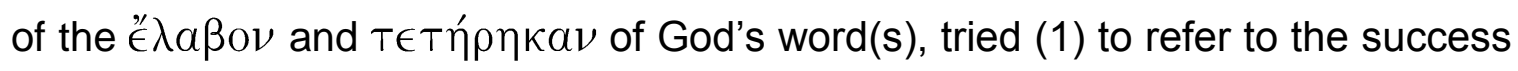
of Jesus' ministry (mission) to his disciples, (2) to cover a broad spectrum (start and result) of the Johannine soteriology by attaching special meaning to these two verbs, and (3) to establish the disciples as worthy agents of Jesus.

\subsection{Faith: "̈ $\gamma \nu \omega \kappa a \nu \ldots$...}

Jesus describes the first reaction of the disciples to the revelation during his earthly ministry as acceptance ('́ $\lambda \alpha \beta O \nu$ - 6.3) - a reaction that contrasted strongly with that of the majority of their contemporaries. They became convinced ( $v v 7,8.3$ ) that Jesus had been sent by God and believed in him (cf vv 25,26 where the verb $\gamma \iota \nu(\omega) \sigma \omega \omega$ also occurs.). This reaction is described in both

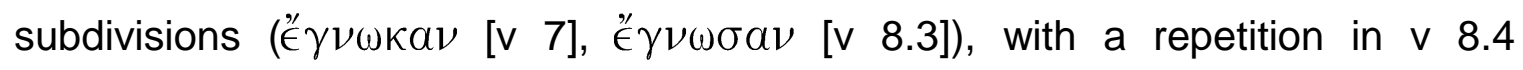

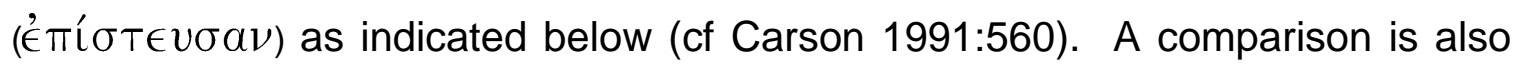
made between 17:8 and 20:31 to indicate the correlation between these texts: 


\begin{tabular}{|c|}
\hline 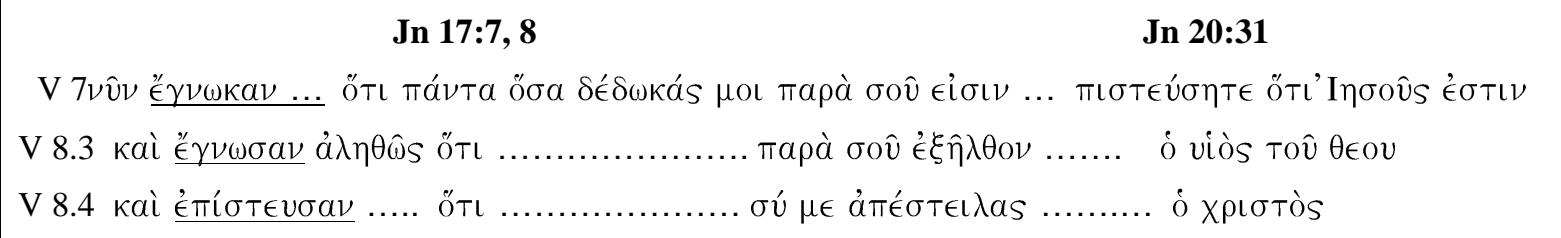 \\
\hline
\end{tabular}

Verse 8.3 and 8.4 form a parallel (cf Barrett 1978:506; Schnackenburg 1988:178): both phrases start with the conjunction kai and end with an ÖTlclause, which is differently formulated but carries a similar reference concerning Jesus' identity (cf Bultmann 1941:382). The two verbs, both in the aorist ('́ $\gamma \nu \omega \sigma \alpha \nu$ and $\underline{\epsilon} \pi \hat{i} \sigma \tau \epsilon v \sigma \alpha \nu$ ), are used as synonyms (cf Brown 1972:44). ${ }^{13}$ The two ÖTL - clauses in vv 8.3 and 8.4 are clearly linked with 20:31, which contributes to the interpretation of these clauses. Verse 8.3 corresponds with the

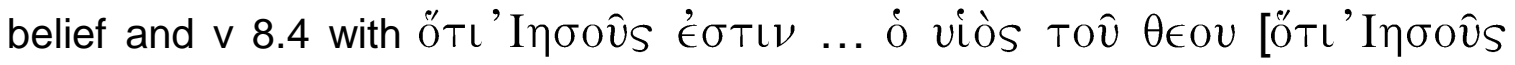

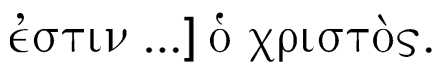

Another parallel occurs between $\mathrm{vv} 7$ and 8.3. The same verb ( $\gamma\llcorner\nu \omega \dot{\sigma} \sigma \kappa \in l \nu$ in the perfect and aorist) is used in both these verses. Both phrases

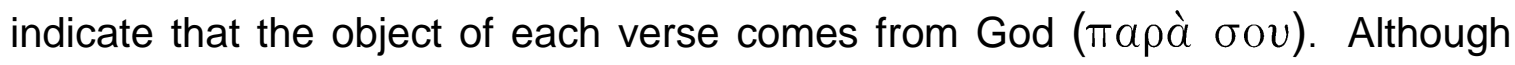
the objects differ, ${ }^{14}$ they carry basically the same meaning, referring to the same object, namely Jesus Christ.

These three equivalent phrases emphasize both the act of faith of the disciples and the content of their faith, which definitely has reached a deeper

\footnotetext{
13 Bernard (1963:565), Barrett (1978:506) and others (cf. Bultmann 1941:333f and 380f) are of

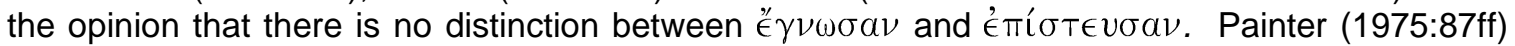
pointed out that the combination of knowing and believing is of fundamental importance in the Fourth Gospel as it draws attention to the Christological understanding of faith (see $\vee 3$ ). When "knowledge" is related to faith, it expresses the perception and understanding component of faith. It may, like believing, also express a partial recognition of Jesus. (3:2; $2: 23 \mathrm{ff})$. Thus, on the one hand, knowledge may lead to authentic faith, because when a person recognizes the need of the gift of eternal life, it opens the way for the question concerning authentic faith $(4: 10 ; 7: 37 \mathrm{ff})$. In terms of development, knowledge constitutes the basis for authentic faith (4:53). On the other hand, faith may open the way to authentic knowledge (8:31f). Abiding in faith brings the knowledge of the truth which sets a person free from sin.

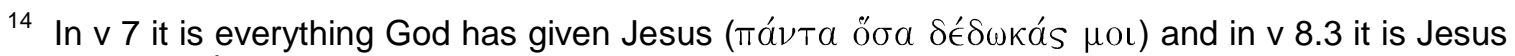
as a person ('ُ $\xi \hat{\eta} \lambda \theta 0 \nu)$.
} 
level (cf 16:30; v 8.3f) (Schnackenburg 1975:201). This distinctive and almost tautological formulation of the knowledge refers to the Father - Son relationship (Schnackenburg 1975:201). These references refer to a certain level of maturity in faith of Jesus' disciples. This level of maturity is indicated by (i) $\pi \alpha ́ \nu \tau \alpha^{15}$ (ô $\sigma \alpha$

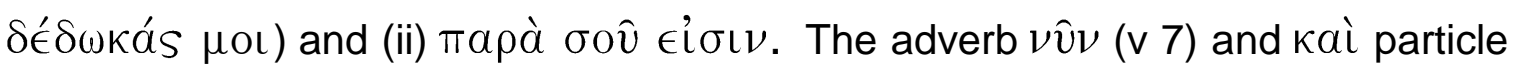
( $v$ 8.3) also draws attention to the level of maturity in faith that has now been reached and indicated by the use of "̈ $\gamma \nu \omega \kappa \alpha \nu$ and É $^{\prime} \nu \omega \sigma \alpha \nu$. Although in 16:30 the disciples claim that they can "see now", their words could not mean much, for it was only after the Passion of Jesus that their knowledge about Jesus' identity (cf 14:15-21) and their self-consciousness about discipleship become real and deliberate (cf Bultmann 1941:381ff; Bernard 1963:564; Lindars 1981:522).

Throughout the prayer the Fourth Evangelist prefers to use the verb

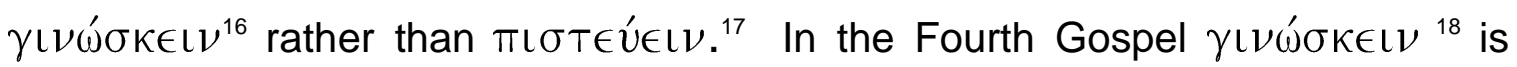
experiential and indicates an intimate relationship (cf Bultmann 1941:381f): "An intimate, mutual relationship exists between the Father and the Son; Jesus in turn knows his disciples, and they know him; and in knowing him they also know God" (see 10:14f) (Ladd 1977:262). The importance of Jesus' mission was to bring men to the knowledge of God. This is seen in the repeated affirmation that the world does not know him $(1: 10 ; 8: 55 ; 16: 3 ; 17: 25)$. But in contrast to the world his disciples do know him $(17: 7,8)$. Knowledge of Jesus is knowledge of the meaning of his mission; he came from God and was sent by God $(17: 8,25)$ (cf Ladd 1977:262).

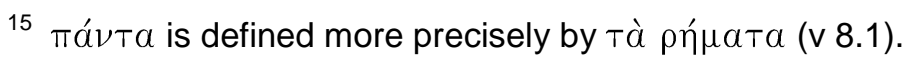

16 Haenchen (1984:151) rightly points out that Jesus' declaration that he had accomplished his task was only possible through a comprehensive view of the totality of the works of Jesus because his earthly life could only be fully comprehended after his death, in other words, is only after his death and resurrection that the significance of his earthly life could be understood.

17 In 17:3 eternal life is attributed to knowledge and in 3:36 to faith. In the present context it refers to a level of faith that is determined by the body of knowledge they possess concerning the Father--Son relationship.

18 Painter (1975:87) maintains that almost $75 \%$ of the occurrences of the word "know" are of theological importance while the rest simply describe knowledge in general.
} 
The criterium that sets Jesus' disciples apart from the world is the fact that they know him while the world does not (17:25). The importance of the mission of Jesus is to bring men to knowledge of God (Ladd 1977:262). But knowledge of God includes knowledge of God's agent and becomes co-terminous with eternal life (17:3) (Schmitz 1976:403). This is best seen in the repeated affirmation of the fact that the world, unlike his disciples, does not know him $(1: 10 ; 8: 55 ; 16: 3 ; 17: 25)$. However, the mission of Jesus is to be extended through his disciples. Through their demonstration of mutual love the world will come to know who Jesus is (17:23). Knowledge of Jesus implies knowledge of the meaning of his mission; he is the Messiah (20:31), the one sent by God (17:8, 25) (Ladd 1977:262). He is the Son of God incarnate (1:14). This implies that the one who sees Jesus sees the Father $(14: 9 ; 12: 45)$ and the one who knows him will know the Father as well, for he has already known him and seen him (14:7). Thus fellowship with God can come only through fellowship with Jesus (Schmitz 1976:404).

In these three references to the content of the disciples' faith we can distinguish three nuances concerning Jesus mission, building up to a climax. In v

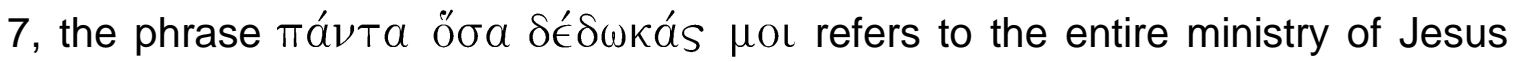
and is recognized as a gift from the Father (Sanders 1975:370). The phrase $\pi \alpha \rho \grave{\alpha} \sigma o \hat{v} \hat{\epsilon} \xi \hat{\eta} \lambda \theta 0 \nu$ in v 8.3 refers to the unity between the Father and the Son, that he came forth from God. This is an essential part of the revelation and is even given a special mention. In $v 8.4$ the Fourth Evangelist wants to emphasize the fact that the disciples finally believe that Jesus is the Messiah. In order for them to believe that Jesus is the Messiah, they first had to believe that God was the source of his ministry and that $\pi \alpha \rho \grave{a} \sigma o \hat{v} \mathfrak{\epsilon}^{\xi} \hat{\eta} \lambda \theta 0 \nu$.

Everything that Jesus received from the Father $(v 7)$ centres in the commission of Jesus (Lenski 1961:1132) and emphasizes the dependence of the Son upon the Father (Newman \& Nida 1980:530). Therefore, the one who knows

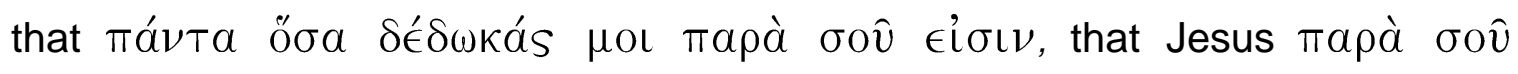

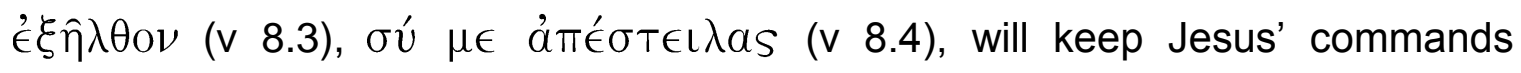
$(14: 15,21,23 ; 15: 10,12,17)$ (cf Schmitz 1976:404). A disciple's $\gamma \iota \nu(\omega) \sigma \kappa \in \iota \nu$ of God or of Jesus expresses itself accordingly in $\dot{a} \gamma a \pi \hat{\alpha} \nu$, while the obeying of the commands might be called the criterion of $\gamma \iota \nu \omega \dot{\sigma} \sigma \in \epsilon \nu$. 
All this leads to the conclusion that these three phrases ( $v v 7,8.3,8.4)$ indicate:

i. The faith-event of the disciples.

ii. The content of their faith. $\Gamma\llcorner\nu \omega \dot{\sigma} \sigma \omega \mathrm{h}$ has a tripple application: (a) to know the love of God which he has shown in the mission of his Son ( $v$ 8.3f) and (b) obedience to the message proclaimed by God's agent (cf Schmitz 1976:404), and (c) that God himself had executed the entire soteriological event.

iii. The elements that legitimize the mission of the disciples. In order to become a disciple of Jesus one has to believe that he was sent by God. Because a disciple has to continue the mission of Jesus, he has to accept Jesus as the Son of God, and the one sent by God. This correlates with the purpose of the message of the

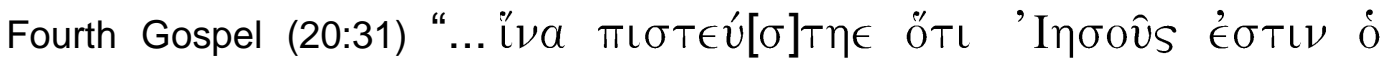
Xpıotòs ó viòs tôิ $\theta \in o \hat{v}$..." By believing this the disciple acknowledges the origin (indicated by ó viòs Tôे $\theta \in \mathrm{O} \hat{\text { ) }}$ ) and mission of Jesus

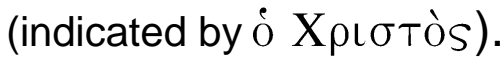

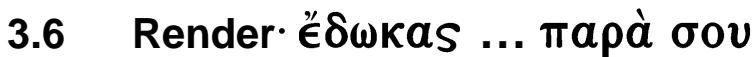

According to Bernard (1963:564; also Ridderbos 1997:552; Lenski 1961:1130) Jesus traces everything back to God himself: "all of his public actions as the manifestation of God's name, all his words and works as given to him by the Father, his entire coming from God and those with whom he now appears before God ...". From $\vee 7$ it is clear that the entire ministry of Jesus is backed by the authority of God (Sanders 1975:370) and this proves that God is always in command.

\section{CONCLUSION}

As has been pointed out in the Introduction the objective was to determine what the Fourth Evangelist wished to emphasize and to communicate concerning the character and success of Jesus' earthly ministry. The Evangelist achieved emphasis through the use of repetition. The typical Johannine spiral of discussion occurred when he successfully moved to a higher level in subdivision $\mathrm{B}$, where he became more specific in the two öTı - clauses. $(v 8.3,8.4)$. 
Jesus' ministry has twice been described in a pregnant sense in the two subdivisions. The parallel used in the two divisions is used in a reciprocal sense in order to clarify mutually the different aspects mentioned in these subdivisions.

Jesus' ministry is depicted here as totally successful through the use of the following verbs, first in the perfect tense and subsequently in the aorist:

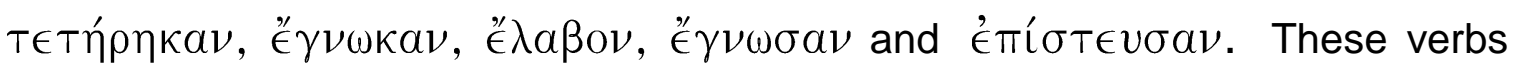
refer to a positive end result.

The character of Jesus' ministry is depicted as the "revelation" of the Father. Two different revelatory verbs have been used: Е $\phi \alpha \nu \epsilon \rho \omega \sigma \alpha$ and $\delta \in ́ \delta \omega \kappa a$. Nonetheless, salvation can be implied, especially on the strength of the verbs used to indicate the success of Jesus' ministry.

A final word is necessary concerning the Father's involvement in the revelatory-salvific mission of Jesus. This has been indicated by the high

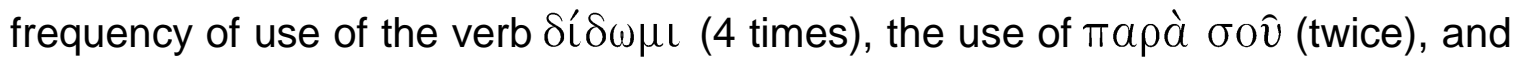
also the use of the two verbs $\dot{\epsilon}^{\xi} \hat{\eta} \hat{\eta} \theta \mathrm{o \nu}$ and $\dot{\alpha} \pi \dot{\epsilon} \sigma \tau \epsilon \mathrm{l} \lambda \alpha \mathrm{s}$ to indicate acts initiated by the Father. The involvement of the Father ensures the success of Jesus' revelatory-salvific mission and guarantees the future continuation and success of this divine mission through the disciples of Jesus.

\section{Works consulted}

Arndt, W F \& Gingrich, F W 1979. A Greek-English Lexicon of the New Testament (2nd ed rev and augm from Walter Bauer's 5th ed, 1958). Chicago: University of Chicago.

Barrett, C K 1978. The Gospel according to St John. London: SPCK.

Bernard, J H 1963. Gospel according to St John. A Critical and exegetical commentary ( Vol 2). Edinburgh: T \& T Clark.

Brown, R E 1972. The Gospel according to John (xiii-xxi) (The Anchor Bible). London: Geoffrey Chapman.

Bultmann, R 1933. Гî $\nu \omega ́ \sigma \kappa \omega$ in Kittel, G (Hrsg). TDNT (Band 1). Stuttgart: Kohlhammer.

Bultmann, R 1941. Das Evangelium des Johannes. Göttingen: Vandenhoeck \& Ruprecht.

Carson, D A 1991. The Gospel According to John. Leicester: Inter-Varsity Press. 
Danker, F W (ed) 2000. Greek-English Lexicon of the New Testament and other Early Christian Literature. Chicago: University of Chicago Press.

Dodd, C H 1980. The Interpretation of the Fourth Gospel. London: Cambridge University.

Haenchen, E 1984. John 1: A Commentary on the Gospel of John, Chapters 1-6 Hermeneia). Philadelphia: Fortress.

Köstenberger, A J 1998. The missions of Jesus \& the disciples according to the Fourth Gospel. Grand Rapids: Eerdmans.

Ladd, G E 1977. A Theology of the New Testament. Grand Rapids: Eerdmans. Lenski, R C H 1961. The interpretation of St John's Gospel. Utah: Provo.

Liddell \& Scott 1974. Greek-English Lexicon. Oxford: The Claredon.

Lindars, B 1981. The Gospel of John. Grand Rapids: Eerdmans. (The New Century Bible Commentary.)

Louw, J P 1982. Semantics of New Testament Greek. Philadelphia: Fortress Press Chico.

Morris, L 1975. The Gospel According to John. Grand Rapids: Eerdmans. (The New International Commentary on the NT.)

Nestle, E \& Aland K 1979 (eds). Novum Testamentum Greece (26th revised edition). Stuttgart: Deutsche Bibelgesellschaft.

Newman, B M \& Nida, E A 1980. A Translators handbook on the Gospel of John. London: United Bible Societies.

Painter, J 1975. John: Witness \& theologian. London: SPCK.

Ridderbos, H 1997. The Gospel of John. Grand Rapids: Eerdmans.

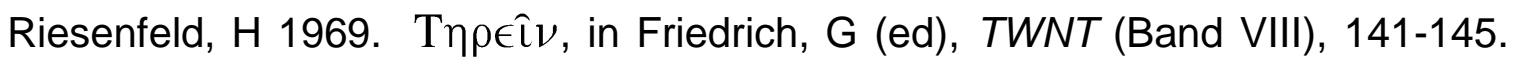

Stuttgart: Kohlhammer.

Sanders, J N \& Mastin, M A 1975. The Gospel According to St John from Blacks' New Testament Commentaries. London: Adam and Charles Black.

Schenke, L 1998. Johannes Kommentar. Düsseldorf: Patmos.

Schmitz, E D 1976. Knowledge, experience, ignorance, in Brown, C (ed). DNTT (Vol II). Exeter: Paternoster.

Schnackenburg, R 1965. Das Johannesevangelium (Teil 1) Einleitung und Kommentar zu Kap. 1-4. Freiburg: Herder.

Schnackenburg, R 1975. Das Johannesevangelium (III Teil). Kommentar zu Kap. 13-21. Freiburg: Hazel. 
Schnackenburg, R 1988. The Gospel according to St John (Vol 3). London: Burns \& Oates.

Schnelle, U 1998a. Das Evangelium nach Johannes. Leipzig: Evangelische Verlagsanstalt.

Schnelle, U 1998b. The history and theology of the New Testament writings. Minneapolis: Fortress.

Schütz, H G 1976. Guard, keep watch, in Brown, C (ed). DNTT (Vol 2). Exeter: Paternoster.

Schwankl, O 1995. Licht und Finsternis (Eis metaphorisches Paradigma in den johanneischen Schrifte). Freiburg: Herder.

Siede, B 1978. Receive, in Brown, C (ed). DNTT (Vol 3). Exeter: Paternoster.

Thompson, M M 2001: The God of the Gospel of John. Grand Rapids: Eerdmans.

Ukpong, J S 1989. Jesus's prayer for his followers (Jn 17) in mission perspective. Africa Theological Journal 18 (1) 49-60.

Van der Merwe, D G 1996. Discipleship in the Fourth Gospel. DD dissertation, Pretoria: University of Pretoria.

Van der Watt, J G 1991. Die Woord het Mens geword: 'n Strukturele uiteensetting van die teologie van die Johannesevangelie, in Roberts, J H \& Vorster, W S Vorster, J N Van der Watt, J G 1991 (reds), Teologie in Konteks. Halfway House: Orion.

Van der Watt, J G 1992. Julle moet mekaar liefhê: Etiek in die Johannesevangelie. Scriptura S9A, 74-96.

Wilckens, U 1998. Das Evangelium nach Johannes. (NTD band 4). Göttingen: Vandenhoeck \& Ruprecht. 